\author{
dr Anna WARCHLEWSKA \\ Katedra Pieniądza i Bankowości, Uniwersytet Ekonomiczny w Poznaniu \\ e-mail: anna.warchlewska@ue.poznan.pl \\ mgr Sylwia GÓRNA, doktorantka \\ Katedra Pieniądza i Bankowości, Uniwersytet Ekonomiczny w Poznaniu
}

DOI: $10.15290 /$ oes.2018.01.91.19

\title{
NOWOCZESNE TECHNOLOGIE JAKO CZYNNIK KONKURENCJI NA LOKALNYCH RYNKACH USLUG BANKOWYCH (NA PRZYKŁADZIE GOSPODARCZEGO BANKU SPÓŁDZIELCZEGO MIĘDZYRZECZ)
}

\begin{abstract}
Streszczenie
Cel - Celem artykułu jest analiza nowoczesnych rozwiązań technologicznych w bankowym sektorze spółdzielczym na rynku lokalnym. W artykule podjęto próbę rozstrzygnięcia, czy wdrażanie nowych technologii w sektorze spółdzielczym przyczynia się do wzrostu ich konkurencyjności.

Metodologia badania - Przedmiotem niniejszego opracowania jest wykorzystanie bankowości elektronicznej w bankowym sektorze spółdzielczym. W opracowaniu weryfikowana będzie hipoteza badawcza, iż klienci GBS Międzyrzecz dostrzegają rosnącą rolę nowoczesnych technologii. Podstawą do analizy były źródła literatury oraz wyniki badań własnych przeprowadzonych wśród klientów GBS Międzyrzecz. Struktura artykułu jest podporządkowana celowi badawczemu.

Wynik - W postępowaniu badawczym zdiagnozowano, iż klienci GBS Międzyrzecz pomimo dostępu do narzędzi do bankowości elektronicznej nie wykorzystują ich w pełni, co nie pozwala na zmianę dotychczasowej postawy. Wskazuje się niedostateczne wykorzystanie zdalnych kanałów dostępu, podczas gdy świadomość klientów GBS Międzyrzecz, o istotnej roli tej usługi jest na wysokim poziomie.

Wartość - Portfel badanego banku nie obejmował na moment badania usługi biometrii, zatem otrzymane wyniki badań mogą stać się przyczynkiem do ich kontynuacji w celu zniwelowania potencjalnych barier i obaw jej wykorzystywania w przyszłości. Upowszechnianie i wdrażanie nowych rozwiązań nie spełni jednakże swojej funkcji bez gruntowego przygotowania zarówno odbiorców, jak i dostawców usług.
\end{abstract}

Słowa kluczowe: nowoczesne technologie, bankowość spółdzielcza, usługi bankowe, bankowość elektroniczna, biometria

\section{MODERN TECHNOLOGIES AS A FACTOR OF COMPETITION ON LOCAL BANKINIG MARKETS (ON THE EXAMPLE OF GOSPODARCZY BANK SPÓEDZIELCZY MIĘDZYRZECZ)}

\section{Summary}

Goal - The aim of this paper is to analysis modern technological solutions in the cooperative banking sector on the local market. The paper is going to resolve if the implementation of new technologies in the BS sector contributes to the increase of their competitiveness. 
Research methodology - The subject of this study is the use of electronic banking in the banking cooperative sector. This paper will be verifying the research hypothesis that the customers of GBS Międzyrzecz perceive the growing role of modern technologies. The source of the analysis was the literature and the results of own research carried out among the clients of GBS Międzyrzecz. The structure of the article is subordinate to the research goal.

Score - The research procedure diagnosed that the customers of GBS Międzyrzecz, despite access to electronic banking tools, don't use them fully, which does not allow changing the current attitude. Insufficient use of remote access channels is indicated, while the awareness of GBS Międzyrzecz clients about the important role of this service is on a high level.

Value - The portfolio of the audited bank did not cover the biometrics service on the research moment, so the obtained research results may become a reason for continuing to eliminate barriers and concerns about its future use. Global use and implementation of new solutions, however, will not fullfill its function without a thorough preparation of both recipients and service providers.

Key words: modern technology, cooperative banking, electronic banking, biometrics

JEL classification: D12, G22, G21, I22

\section{Wstęp}

Dynamiczny rozwój rynków finansowych wpłynął na intensyfikację działań banków spółdzielczych w obszarze innowacji technologicznych. Wobec zmieniających się warunków gospodarczych, obserwuje się dużą zdolność banków spóldzielczych do dopasowania się do instytucji konkurencyjnych. Przyczyn implementacji nowoczesnych rozwiązań technologicznych należy upatrywać w deregulacji rynków finansowych i zniesieniu barier ograniczających konkurencję, szczególnie na rynku bankowym.

Lokalność działania banków spółdzielczych stanowi istotę funkcjonowania i przetrwania na rynku usług bankowych. Przedstawiana cecha lokalności w literaturze, wynika z przesłanek historycznych oraz z tradycji ruchu spółdzielczego [Rosa, 2013, s. 517-528]. Wzrost znaczenia rozwoju nowoczesnych usług i produktów w bankach spółdzielczych, wynika m.in. z chęci pozostania na rynku, podążania za trendami i ewolucja potrzeb klientów. Wybór banku do badania podyktowany był dążeniem do empirycznego badania opinii na temat nowych technologii osób zamieszkujących mniejsze miejscowości, z rejonu dobrze znanego przez jedną $\mathrm{z}$ autorek $\mathrm{z}$ uwagi na jej miejsce zamieszkania. Struktura artykułu została podporządkowana realizacji przyjętego celu i składa się z czterech części. Pierwsza z nich przedstawia podział bankowości elektronicznej i ewolucję nowoczesnych technologii. Druga część artykułu dotyczy istoty wdrażania nowoczesnych technologii na rynku lokalnym w banku spółdzielczym w Międzyrzeczu. W części trzeciej zaprezentowano wyniki badań własnych dotyczących wykorzystania nowoczesnych rozwiązań technologicznych i produktowych na przykładzie Gospodarczego Banku Spółdzielczego Międzyrzecz. Ostatnią część opracowania stanowi zakończenie. 


\section{Ewolucja nowoczesnych technologii}

Za najbardziej dynamiczny okres rozwoju technologicznego uznaje się koniec XX wieku, w którym dokonał się przełom na gruncie łączności i telekomunikacji, co znacznie ułatwiało pojawianie się kolejnych rozwiązań. Jest to niezwykle ważne, gdyż współcześnie społeczeństwa uzależnione są od tego typu technik przesyłania informacji, dlatego też ich popularność wzrasta [Janc, 2004, s. 13]. Efektem tego jest wzmożona rola usług e-bankowości i e-płatności w życiu każdego konsumenta i dążenie instytucji finansowych do kształtowania nowych form płatności [Świecka 2008, s. 8]. Dokonujące się odkrycia dały szansę na zmniejszenie kosztów. Pamięć komputerów stała się tańsza na skutek wynalezienia nośników magnetycznych oraz komputerów klasy PC. Pojawiła się również szansa na zastapienie dokumentów w formie papierowej formą elektroniczną, co stało się powodem szybszego dostępu do informacji. Niezwykle ważnym odkryciem był telefon komórkowy, a w połączeniu z komputerem i dawna siecia ARPANET (Advanced Research Projects Agency Network) - Internetem - jego użyteczność znacznie wzrosła. Dało to początek wielokanałowości, czyli rozprzestrzeniania usług bankowych w konkretnych grupach klientów, uwzględniając ich preferencje [Janc, 2004].

Dokonania w zakresie telekomunikacji, komputerów, Internetu i smartfonów przyczyniły się do rozwoju usług bankowych, przez co ewoluowała i wciąż ewoluuje bankowość elektroniczna. Szacuje się, że początek bankowości elektronicznej to 1962 rok, gdy w Banku Wirginii zainstalowano pierwszy elektroniczny wielofunkcyjny terminal ATM, służący do wypłaty środków, dokonania przelewu i sprawdzenia stanu środków na rachunku [Dokument elektroniczny, tryb dostępu: http://www. ioz.pwr.wroc.pl/Pracownicy/mercik/zbiory/ Prezentacje\%202007/ grupa4-20Bankowo.pdf, data wejścia: 11.01.2017]. Z kolei Stany Zjednoczone już od 1918 roku zaczęły wykorzystywać łącza telegraficzne dla celu realizacji transakcji rynku międzybankowego. Od lat 60. XX wieku, za sprawą Luthera G. Simjiana, możliwa była pierwsza wypłata środków z bankomatu [Dokument elektroniczny, tryb dostępu: http://www.forbes.pl/historia-bankomatu,artykuly,195302,1,1.html, data wejścia: 02.01.2017]. W 1994 roku zaczęto świadczyć usługi bankowe za pośrednictwem Internetu. Bankowość elektroniczna w Polsce popularna jest od 1993 roku, w którym Bank Rozwoju Eksportu S.A. wprowadził obsługę rachunków na zasadzie home bankingu, która polegała na obsłudze rachunku bankowego, bez konieczności wychodzenia z domu, przez sieć telefoniczna, komórkową i wykorzystanie przystosowanego oprogramowania. Pięć lat później wprowadzona została bankowość internetowa (jako jedna z kategorii bankowości elektronicznej), która okazała się dużym sukcesem [Ślązak, Borowski 2007, s. 231]. Komisja Nadzoru Finansowego [KNF 2010, s. 6] klasyfikuje bankowość elektroniczną na:

- terminalowa,

- internetowa,

- mobilna.

$\mathrm{Na}$ potrzeby niniejszego opracowania przyjmuje się klasyfikację rozszerzoną o usługę bome banking. 
Bankowość terminalowa uznawana jest za najpopularniejszą i najczęściej stosowaną formę bankowości elektronicznej. Polega na dokonywaniu transakcji za pośrednictwem terminali POS i bankomatów, z wykorzystaniem kart płatniczych. Pierwszym przeznaczeniem bankomatów była wypłata gotówki, jednak zakres ich działania rozszerzył się i obecnie w bankomatach można składać depozyt [Górka, 2006, s. 11], czy uzyskać bon z kodem kreskowym bezpośrednio przeznaczonym na zakupy w sklepie, w pobliżu którego znajduje się urządzenie [Dokument elektroniczny, tryb dostępu: http://www.automatykabankowa.pl/bankomat-bezgotowkowy-ciekawostka-czy-rewolucja-w-wyplatach-samoobslugowych-w-firmach-retail/, data wejścia 04.01.2017].

Niekorzystne zmiany dotyczą wzrastającej liczby przestępstw w obszarze bankowości terminalowej (skimmingu) - montowanie przez przestępcę kamery w bankomatach oraz jednoczesne skanowanie paska magnetycznego karty, które w sposób sprzeczny z prawem, pozwala wypłacić środki posiadacza karty [Dokument elektroniczny, tryb dostępu: www.ptzp.org.pl ${ }_{2}$ data wejścia: 11.01.2017].

Bankowość internetowa to sposób dokonywania operacji bankowych zdalnie z wykorzystaniem komputera, dostępu do Internetu oraz przegląarki internetowej. Umożliwia realizacje wszystkich transakcji bankowych klienta pod warunkiem łączności z bankiem w czasie rzeczywistym (on-line), [Ślązak, Borowski, 2007, s. 231]. Bankowość internetową cechuje małe zaangażowanie liczby osób do obsługi, co skutkuje redukcją kosztów operacyjnych banku i ograniczeniem liczby oddziałów. Należy nadmienić, iż istnieja przykłady „czystej” bankowości internetowej - tzw. banki wirtualne, które obsługują swoich klientów wyłącznie drogą internetową oraz telefoniczną, nie posiadając oddziałów. Należą do nich m.in. Inteligo oraz mBank [Parys, 2003, s. 193-201].

Bankowość mobilną próbowano wdrażać już w latach 90. XX wieku za pomoca technologii WAP. Największą popularność zyskała ona jednak, gdy wynaleziony został telefon komórkowy. Wówczas istniała możliwość świadczenia usług bankowych przez aplikacje telefoniczne [Dokument elektroniczny, tryb dostępu: World Economic Forum 2009, data wejścia 11.01.2017]. Popularność mobilnego kanału dostępu do usług bankowych wciąż rośnie. Na koniec III kwartału 2016 roku użytkowników korzystających z tego rodzaju bankowości było w Polsce 7,1 mln osób i jest to wzrost o 0,8 tys. w porównaniu z II kwartałem 2016 roku [Dokument elektroniczny, tryb dostępu: PRNews.pl 2016, data wejścia: 16.01.2017]. Uznaje się, że bankowość mobilna jest najkorzystniejszym rodzajem bankowości elektronicznej, gdyż wysoce mobilny telefon minimalizuje znaczenie czasu dla wydania dyspozycji realizacji transakcji oraz miejsca pobytu klienta banku [Zalewska-Bochenko, 2003, s. 303]. Pierwsza aplikacja mobilna (bPay) w sektorze spółdzielczym została wdrożona przez Bank Spółdzielczy we Wschowie w 2012 roku. Aplikacja posiada funkcje sprawdzania stanu konta, klienci moga realizować przelewy, zakładać lokaty, sprawdzać dostępność bankomatów w okolicy i przeglądać kursy walut [Dokument elektroniczny, tryb dostępu: https://bodie.pl/blog/masz-bank-pod-reka,22?p=8, data wejścia: 04.02.2018]. 
Innym kanałem dystrybucji usług bankowości elektronicznej jest home banking. Przesłanką za jej powstaniem była potrzeba korzystania z usług bankowych w domu. Jako pierwsze, z początkiem lat 80. zaczęły wdrażać ją banki amerykańskie m.in. Citibank, czy Chase Manhattan Bank [Gawrychowski, 2016, s. 106]. Z tego rodzaju usługi można korzystać przez dostęp do dedykowanego oprogramowania na komputerze klienta lub dostęp do Internetu (przy czym nie jest to warunek konieczny), [KNF, 2010, s. 25]. Ten rodzaj usługi dominuje na rynku bankowości korporacyjnej, a zatem najczęściej preferowana jest przez przedsiębiorstwa [Polasik 2005, s. 59], jednakże współcześnie zainteresowanie tą usługą maleje, gdyż rośnie popularność rozwiązań on-line.

Niewątpliwie, głównymi przesłankami za dążeniem banków do wdrażania technologicznych rozwiązań jest usprawnianie świadczenia usług, dzięki przezwyciężaniu barier organizacyjnych i czasowych oraz dostosowanie się do preferencji uczestników rynku finansowego [Polasik, 2006, s. 35-36]. Ponadto, sektor bankowy skupia dużą uwagę wokół niższych kosztów obsługi przez eliminację droższej, papierowej formy rozliczeń lub obsługi konta osobistego tylko przez zdalne kanały obsługi. W kontekście dążenia banków do doskonalenia technologii ważnym czynnikiem może być również zwiększona świadomość społeczeństwa oraz wzrastający poziom wykształcenia ludności. Doświadczenie oraz czerpane wzorce z krajów sąsiednich moga nierzadko wymuszać na bankach konieczne, technologiczne zmiany [Martyniuk, 2007, s. 292, 297]. Specyfika banków spółdzielczych skłania je do działań o charakterze społecznym, zgodnych z zasada , miejscowy pieniądz na potrzeby miejscowej społeczności" [Szambelańczyk, 2004, s. 152], która nawiązuje m.in. do teorii zrównoważonego rozwoju i koncepcji zrównoważonych finansów. Przedsięwzięcia społecznie użyteczne, dbanie o wizerunek przez wrażliwość na ludzkie potrzeby, tj. działanie na korzyść interesariuszy sa głównymi wyznacznikami owej koncepcji [Gasparski, 2012, s. 474-478]. W praktyce jest to wykorzystywanie elementów koncepcji społecznej odpowiedzialności biznesu (corporate social responsibility), takich jak finansowanie lokalnych wydarzeń kulturalnych, działalność charytatywna, czy bezpłatna edukacja finansowa [Czechowska, 2013, s. 47]. Kwestię doboru technologii należy także uzależniać od struktury klientów banków. W ramach teorii starzejącego się społeczeństwa (silver economy) coraz częściej podejmuje się dyskusję nad udogodnieniami dla osób starszych, które literatura przedmiotu definiuje jako gerontechnologie [Klimczuk, 2012, s. 52]. Zdaniem autorek jest to wyzwanie nie tylko dla sektora publicznego, lecz także dla sektora bankowego, gdzie technologia biometryczna oprócz korzyści dla klienta, przedstawionych w tabeli 1, może okazać się szybszym i prostszym sposobem dokonywania standardowych transakcji przez osoby w wieku senioralnym.

Biorąc pod uwage wpływ nowych technologii na działalność banków należy także uwzględnić kwestie prawne. Banki, jako organy prowadzące rachunki bankowe klientów zobowiązane sa do dochowania szczególnej dbałości w zakresie bezpieczeństwa środków [KNF, 2010, s. 29]. Podstawowym aktem prawnym regulującym działalność banków jest ustawa z dnia 29 sierpnia 1997 r. Prawo Bankowe [Dz. U. 1997 nr 140 poz. 939]. Istniejące w niej zapisy stanowią, iż oświadczenia woli, 
związane czynnościami bankowymi, mogą zostać złożone droga elektroniczna, z wykorzystaniem elektronicznych nośników informacji. Banki, które funkcjonują w formie spółek akcyjnych zobowiązane są do wykonywania czynności bankowych zgodnie z ustawa z dnia 15 września 2000 r. Kodeks spółek handlowych [Dz. U. 2000 nr 94 poz. 1037]. Podmioty, które funkcjonują na zasadzie spółdzielni działaja zgodnie z ustawą z dnia 7 grudnia 2000 r. o funkcjonowaniu banków spółdzielczych, ich zrzeszaniu się i bankach zrzeszających [Dz. U. 2000 nr 911 poz. 1252]. Rozliczenia pieniężne pomiędzy bankiem a jego klientem moga być dokonywane $\mathrm{w}$ formie gotówkowej (osobiście w oddziale) lub w formie bezgotówkowej (za pomoca karty płatniczej). Ta ostatnia jest regulowana ustawa z dnia 19 sierpnia 2011 roku o usługach płatniczych [Dz. U. 2011 nr 199 poz. 1175], na mocy której bank zobowiazuje się do umożliwienia (za pomocą urządzeń łączności) klientowi dostępu do środków i realizacji operacji z konta. Nadrzędnym dokumentem jednak jest umowa o prowadzenie rachunku, czy też umowa o korzystanie $z$ usługi elektronicznej zawarta pomiędzy bankiem a klientem oraz regulamin, sporządzony zazwyczaj indywidualnie przez dany bank, w którym znajdują się informacje ogólne, niewymagające podpisu posiadacza rachunku [KNF, 2010, s. 6].

Analizując specyfikę podejścia banków spółdzielczych i komercyjnych do obsługi klienta, to właśnie sektor spółdzielczy cechuje tradycyjne podejście. W strukturze banków spółdzielczych najczęściej dominują banki o wartości kapitału nieprzekraczającej $10 \mathrm{mln}$ zł i zakresie działalności niższej niż w sektorze komercyjnym, czego konsekwencją są mniejsze zdolności operacyjne. Banki spółdzielcze stosują zbliżoną politykę kadrowa, zatrudniając około 50 pracowników, spośród których tylko część przechodzi specjalistyczne szkolenia w zakresie informatyzacji, $\mathrm{i}$ to na nich spoczywa odpowiedzialność za prawidłowość wdrożeń rozwiazzań technologicznych. Odmienna sytuacja występuje w bankach komercyjnych, w których dział informatyczny tworzą wysoko wyspecjalizowane firmy doradcze, których budżet jest wyższy, a działanie opiera się na wypracowanych przez lata schematach [Kotliński, 2012, s. 262]. Banki spółdzielcze wykazują dużą otwartość na nowe technologie, co jest wynikiem prowadzonej polityki podmiotów konkurencyjnych w sferze produktów, zarządzania i technologii. Przykładem może być po raz pierwszy w Europie zastosowana technologia biometryczna finger vein, polegająca na skanowaniu naczyń krwionośnych palca. Wdrożył ją Bank Polskiej Spółdzielczości oraz Podkarpacki Bank Spółdzielczy. Na koniec III kwartału 2016 roku system uwierzytelniania biometrycznego wdrożyło ponad 50 banków spółdzielczych [Pawęda, 2016, s. 50]. Technologia biometryczna pozwala klientom w szybki, wygodny i bezpieczny sposób uzyskać dostęp do gotówki z bankomatu, dokonać wpłaty we wpłatomacie, bez konieczności użycia karty i autoryzacji PIN-em. Zastosowanie wdrożonego oprogramowania może być także wykorzystane m.in. do logowania pracowników do systemu, zatwierdzania transakcji, autoryzacji operacji kasowych przez klientów lub potwierdzania tożsamości klientów podczas wizyty w placówce banku [Dokument elektroniczny, tryb dostępu: https://www.novum.pl/index.php/biometria-w-bankach-spoldzielczych, data wejścia: 07.02.2017]. 
TABELA 1.

\section{Korzyści dla banku z zastosowania technologii uwierzytelniania biometrycznego}

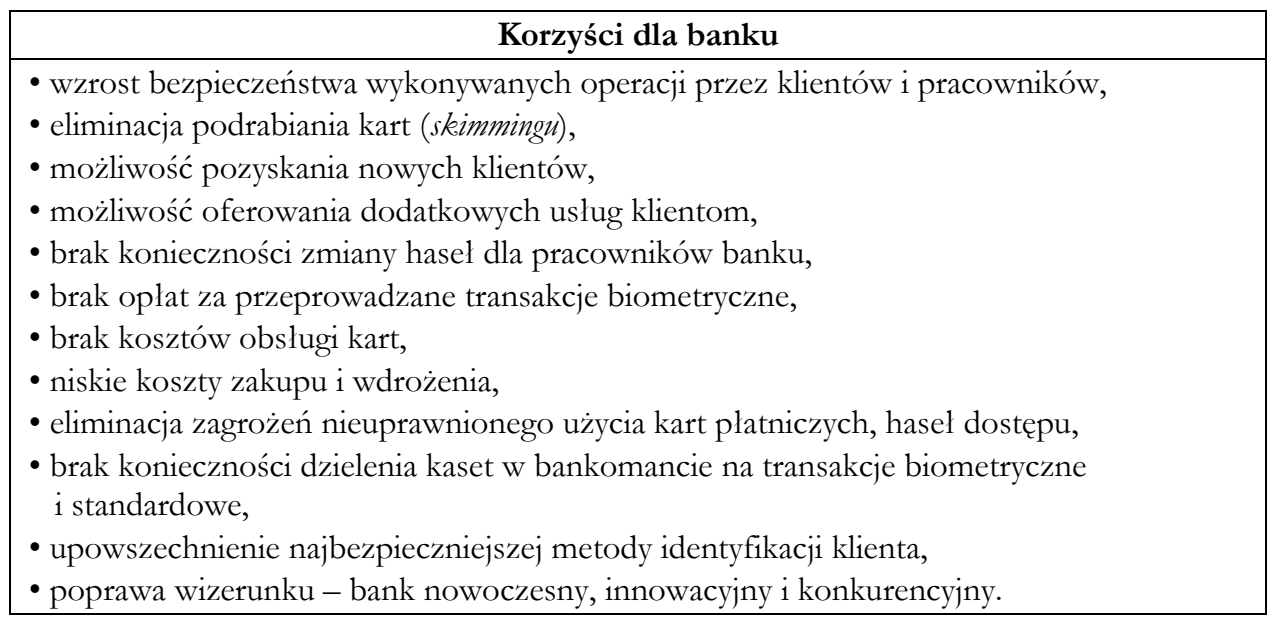

Źródło: [dokument elektroniczny, tryb dostępu: https://www.novum.pl/index.php/biometria-w-bankach-spoldzielczych, data wejścia: 07.02.2017].

Dzięki zastosowaniu technologii uwierzytelniania biometrycznego banki spółdzielcze mogą odnosić szereg korzyści dla siebie (tabela 1) i dla klientów (tabela 2). Wzrost bezpieczeństwa to niewątpliwe główna korzyść dla obu stron. Przede wszystkim bezpieczeństwo realizowanych transakcji przez klientów i pracowników banku, wyeliminowanie pomyłek i nieuprawnionych działań na rachunkach bankowych. Niskie koszty wdrażania autoryzacji biometrycznej powinny być przyczyną wzmożonej aktywności kolejnych banków spółdzielczych w tym obszarze i czynić je bardziej konkurencyjne ze względu na wprowadzanie mniej powszechnych jak dotąd „nowinek”.

Z drugiej strony, wdrożenie technologii uwierzytelniania biometrycznego może nieść ze sobą obawy klientów banków dotyczące m.in. bezpieczeństwa zdeponowanych środków, wątpliwości w zakresie ochrony danych osobowych. Wystapić mogą również problemy dotyczące obsługi swoich produktów z wykorzystaniem biometrii. Innowacyjność uwierzytelniania biometrycznego bez watpienia wymaga edukacji na poziomie oddziału banku, a także dystrybucję filmów szkoleniowych. 
TABELA 2.

\section{Korzyści dla klienta z zastosowania technologii uwierzytelniania biometrycznego}

\begin{tabular}{|l|}
\hline \multicolumn{1}{|c|}{ Korzyści dla klienta } \\
\hline - brak możliwości podszycia się pod innego klienta, \\
- najbezpieczniejszy sposób realizowania transakcji w urządzeniach bankomatowych, \\
- eliminacja podrabiania kart (skimming), \\
- wypłata gotówki bez użycia karty i kodu PIN, \\
- brak dokumentów, utrata karty nie ogranicza korzystania z usług banku, \\
- bezpieczeństwo konta klienta w przypadku utraty/kradzieży karty i dokumentów, \\
- wygodne rozwiązanie dla klientów niepełnosprawnych, \\
- szybkość transakcji, uwierzytelnianie trwa mniej niż 1 sekundę.
\end{tabular}

Źródło: ibidem.

Aby dokonać oceny konkurencyjności banków spółdzielczych przez pryzmat implementacji nowoczesnych technologii, należy wyjść od definicji tegoż pojęcia. Literatura przedmiotu bardzo szeroko opisuje ten termin, wskazując, że konkurencyjność jest procesem, w którym podnosi się zdolności efektywnego funkcjonowania oraz stwarzania i utrzymywania narzędzi konkurowania, dzięki czemu utrzymuje się przewagę konkurencyjną na rynku [Gorzeń, Mitka, 2014, s. 8]. W długim okresie jest to cecha organizacji, która potrafi przetrwać [Gorynia, Jankowska, 2008, s. 51]. Badania naukowe nad konkurencyjnością i konkurencją w sektorze banków prowadzone są w odniesieniu do skali mikro, gdzie podmioty, tj. banki, modelowane są jako jednostki niezależne, które w sposób optymalny reagują na bodźce rynkowe [Pawłowska, 2014, s. 25]. W odniesieniu do działalności banków spółdzielczych, które cechuje wysoka elastyczność, zauważyć można, że przez mniej skomplikowane struktury organizacyjne szybciej potrafią reagować na zmiany rynku. Szybkość realizacji to tylko jeden z czynników, jakie zostały zaproponowane w literaturze [Gorynia, Jankowska, 2008, s. 57-58]. Ponadto, ważnym elementem charakteryzującym potencjał konkurencyjny przedsiębiorstwa jest m.in. opanowanie technologii. Fakt ten utwierdza w przekonaniu, że wykorzystanie technologii w bankach spółdzielczych jest istotnym komponentem strategii banków, a w połączeniu z relatywnie lepszą elastycznością, mają one szansę na oferowanie produktów „szytych na miarę klientów”.

Nowoczesne technologie zaznaczają się coraz silniej w zakresie usług bankowych, a przynajmniej rekomenduje się ich wdrażanie. Takich kierunków zmian oczekiwać będa przedsiębiorcy, którzy nie mając czasu na wizyty w oddziale, posłużą się kanałem zdalnym [Orłowski, 2016, s. 14-15]. Z drugiej jednak strony, nowoczesne technologie stanowić mogą barierę dla klientów przywiązanych do tradycji, niezdecydowanych, obawiających się o bezpieczeństwo transakcji oraz osób zagrożonych wykluczeniem ze świata finansów [Warchlewska, 2012, s. 169-178]. 


\section{Działalność Gospodarczego Banku Spółdzielczego Międzyrzecz w obszarze wdrażania nowoczesnych technologii na rynku lokalnym}

Istniejący (data wpisu do KRS) od 1975 roku Gospodarczy Bank Spółdzielczy Międzyrzecz (GBS Międzyrzecz) [Dokument elektroniczny, tryb dostępu: http:// www.krs-online.com.pl/gospodarczy-bank-spoldzielczy-miedzyrzecz-archiwum6837636-80090.html, data wejścia: 12.01.2017] swoją działalność prowadzi w województwie lubuskim, na znacznym obszarze powiatu międzyrzeckiego oraz części powiatu świebodzińskiego [Dokument elektroniczny, tryb dostępu: http://www. gbsmiedzyrzecz.pl/o-nas/placowki.html, data wejścia: 12.01.2017].

Klienci obsługiwani sa w 5 oddziałach, 3 filiach i 2 punktach kasowych. Na terenie prowadzonej działalności Bank posiada 7 bankomatów [Dokument elektroniczny, tryb dostępu: http://www.gbsmiedzyrzecz.pl/o-nas/bankomaty.html, data wejścia: 13.01.2017].

Polityka kadrowa odbiega od przeciętnego na rynku, gdyż jako bank lokalny zatrudnia 76 osób i jest to więcej niż przeciętne zatrudnienie w sektorze bankowym wynoszącym 56,8 etatu w I kwartale 2016 roku. Na koniec 2016 roku na skutek zamknięcia jednego z oddziałów Banku, liczba pracowników GBS Międzyrzecz nieznacznie uległa zmniejszeniu, co jest odzwierciedleniem trendu zachodzącego w całym sektorze spółdzielczym od 2013 roku [KNF, 2016, s. 9-10]. W GBS Międzyrzecz rachunek bankowy posiada prawie 14 tysięcy klientów.

Bankowość internetowa (system I-Bank) w analizowanym banku dostępna jest od 2005 roku. Usługa ta jest skierowana przede wszystkim do klientów indywidualnych oraz przedsiębiorców. Klient realizując przelew z miejsca, w którym posiada dostęp do Internetu może autoryzować transakcję za pomocą kodu SMS lub klucza cyfrowego. Dodatkowo Gospodarczy Bank Spółdzielczy Międzyrzecz wdrożył usługę Mobile Banking, która przeznaczona jest przede wszystkim dla klientów indywidualnych i klientów instytucjonalnych z jednoosobową autoryzacja. Usługa ta jest dostosowana dla telefonów, smartfonów oraz tabletów, które posiadają ekran dotykowy i przeglądarkę internetową [GBS Międzyrzecz, 2014]. Wykres 1 przedstawia odbiorców usług bankowości internetowej w GBS Międzyrzecz w latach 2011-2016.

Analiza danych na wykresie 1 wskazuje, że w 2016 roku w stosunku do roku 2015 bankowość internetowa była bardziej popularna forma kontaktu z bankiem wśród osób fizycznych (2535) niż wśród pozostałych klientów (547). Świadczy o tym nasycenie rynku, co przedstawia krzywa dotycząca klientów z grupy „pozostali”, która wskazuje niewielki wzrost udziału nowych klientów na przestrzeni 6 lat (+194). Analiza drugiej grupy odbiorców usług bankowości internetowej przedstawia stopniowy wzrost udziału klientów indywidualnych, który od roku 2015 również wyhamował.

Za jeden z najbardziej innowacyjnych projektów, obok bankowości mobilnej wdrożonej na początku 2014 roku, uznaje się wdrożony system zbliżeniowych płatności mobilnych Visa w Spółdzielczej Grupie Bankowej S.A., nad którym zakończono pracę w listopadzie 2016 roku (w sierpniu 2016 roku przeprowadzano 
badanie pilotażowe w 6 bankach z grupy SGB). Data ta zapoczątkowała możliwość oferowania tej innowacyjnej usługi przez Bank Zrzeszający oraz Banki Zrzeszone w grupie SGB [Dokument elektroniczny, tryb dostępu: https://www.visa.pl/o-nas/ aktualnosci/mobilne-platnosci-zblizeniowe-visa-oparte-o-chmure-w-spoldzielczejgrupie-bankowej-1666262?returnUrl=/o-nas/aktualnosci/index, data wejścia: 12.01. 2017], w tym przez Bank, który podlega analizie w niniejszym opracowaniu. System płatności mobilnych HCE (Host Card Emulation) oparty jest na technologii NFC (Near Field Communication) powstał przy współpracy z firmą First Data Polska S.A. (wybierając usługę First DataTM Mobile Platform $\left.{ }^{\circledR}\right)$, która specjalizuje się w obsłudze płatności elektronicznych w Internecie [Dokument elektroniczny, tryb dostępu: http://serwisy.gazetaprawna.pl/finanse-osobiste/artykuly/970019, platnosci-hce-w-bankach-spoldzielczej-grupy-bankowej.html, data wejścia: 12.01. 2017].

WYKRES 1.

Odbiorcy bankowości internetowej w GBS Międzyrzecz

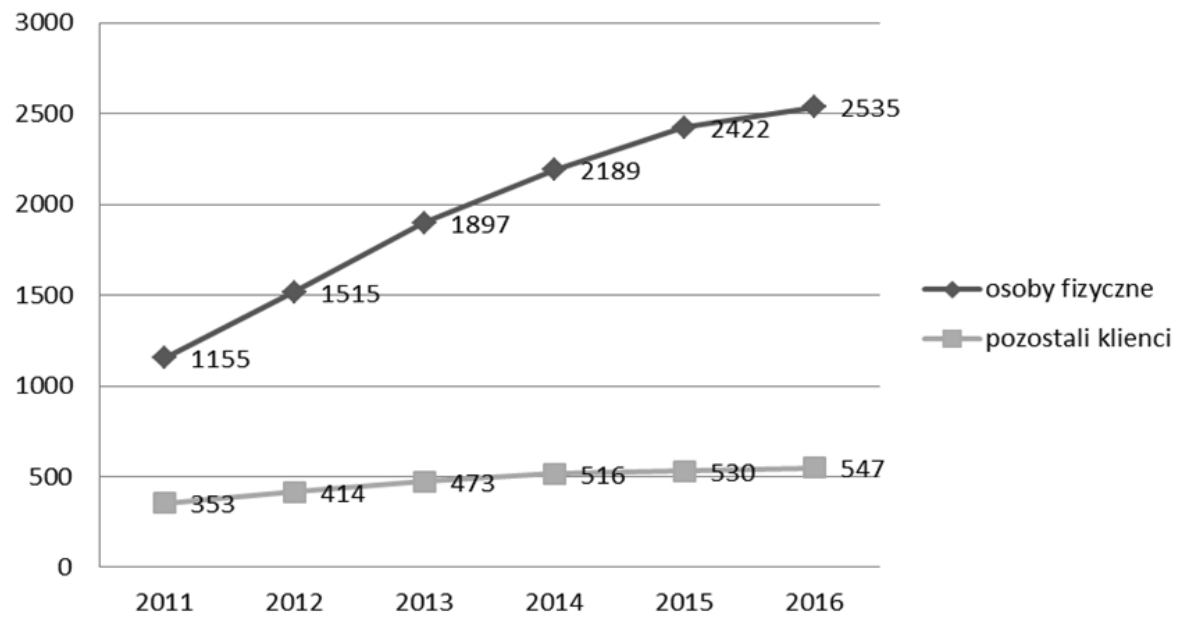

Grupa „pozostali” obejmuje: podmioty gospodarcze, rolników, spółki oraz przedsiębiorstwa państwowe.

Źródło: opracowanie własne.

Aby zrealizować płatność klient posiadający rachunek w banku zobowiązany jest do wypełnienia wniosku oraz na mocy umowy z bankiem, w smartfonie zostanie zainstalowana karta Visa. Smartfon musi spełnić określone wymogi, musi być wyposażony w system Android (minimum 4.4), posiadać dostęp do Internetu, za pomocą którego pobrana została aplikacja „Portfel SGB” udostępniona w sklepie Google Play. Klient, chcąc zapłacić telefonem w sklepie będzie musiał zbliżyć telefon do terminala POS w czasie około 15 sekund. Aplikacja ta nie wymaga wyrobienia specjalnej karty SIM oraz nie jest konieczne posiadanie rachunku w banku, który współpracuje z operatorem [SGB, 2016, s. 17-18]. Działa na podobnych zasadach jak karta zbliżeniowa, gdzie konieczne jest potwierdzenie transakcji kodem PIN 
powyżej wartości 50 zł. Mankamentem jest jednak fakt, że osoby korzystające z systemu operacyjnego IOS przeznaczonych dla urządzeń firmy Apple są wyłączone z możliwości korzystania $z$ tej innowacyjnej usługi.

Dostosowywanie oferty do rozwijającego się rynku usług bankowych i wprowadzanie ulepszeń technologicznych zostanie, zdaniem autorek, docenione przez klientów, ponieważ są oni uznawani za lojalnych, ze względu na lokalny charakter działalności banku oraz długoletnią tradycję i rozpoznawalność marki [Dokument elektroniczny, tryb dostępu: http://www.bankier.pl/wiadomosc/Za-co-chwalimybanki-spoldzielcze-2555338.html, data wejścia: 14.01.2017]. Bank obsługuje klientów, którzy preferują tradycyjną bankowość, a zatem wybierają bezpośredni kontakt z pracownikiem banku, co również właściwie oddziałuje na relacje. Jak wynika z badania Deloitte, $90 \%$ sprzedaży usług bankowych dokonywana jest w oddziale [Deloitte, 2015]. Co więcej, ze względu na rozmiary działania, a co z tym związane, niższy budżet, niewłaściwe byłoby ciagłe powielanie wzorców sektora komercyjnego przez banki spółdzielcze [Mórawski, 2016, s. 24-26]. Oddziały banków komercyjnych, które stanowią konkurencję dla analizowanego banku należy uznać za pionierów technologii w bankowości mobilnej. Aplikacja BLIK została wdrożona w 2015 roku i jednym z sześciu banków był także BZ WBK S.A., którego oddział znajduje się w Międzyrzeczu. Ponadto warto zwrócić uwagę, że Bank PKO BP S.A. tożsame rozwiązanie (aplikacja IKO) z sukcesem udostępnił już w 2014 roku [Dokument elektroniczny, tryb dostępu: http://www.pkobp.pl/grupa-pko-bankupolskiego/pko-bank-polski/historia/rys-historyczny/, data wejścia: 15.01.2017 r.]. Skorzystało z niego łącznie ponad 200 tys. klientów, dokonując $1,7 \mathrm{mln}$ transakcji na sumę ponad $580 \mathrm{mln}$ zł [Dokument elektroniczny, tryb dostępu: http://www. spidersweb.pl/2015/02/blik-start-platnosci.html, data wejścia: 14.01.2017].

Obserwuje się rozwój gospodarczy na badanym obszarze przez rozrastający się Park Przemysłowy. Na obszarze Międzyrzecza działalność prowadzą średnie oraz duże przedsiębiorstwa, $\mathrm{z}$ kolei $\mathrm{w}$ sąsiednich, mniejszych miejscowościach funkcjonuja niewielkie zakłady. Każdy następny, który rozpoczyna działalność na lokalnym terenie jest dla banku szansą na pozyskanie nowego klienta. Kolejna, pomyślna perspektywą dla banku jest przeważająca liczba ludności w wieku produkcyjnym (18-64) w podregionie gorzowskim (na którego obszarze znajduje się powiat międzyrzecki), która stanowi 63\% populacji [GUS 2016]. Osoby te wykazują wyższą skłonność do korzystania z nowoczesnych usług bankowych. Potwierdzeniem powyższej analizy i zachowań konsumenckich mogą być wyniki badania z 2013 roku Zwyczaje platnicze Polaków przeprowadzanego przez Narodowy Bank Polski, które wskazują, że największy odsetek płatności kartą dokonały osoby w przedziale wieku 25-44 lat [Koźliński, 2013, s.64-65] i realizują w formie bezgotówkowej prawie 50\% swoich wydatków [ibidem, s. 139-141].

Obszar zarządzania nowoczesnymi technologiami w bankowości oraz przestrzegania zasad bezpieczeństwa sfery teleinformatycznej reguluje Rekomendacja D wydana w drodze uchwaly [7/2013]; [KNF, 2013]. Zarząd Banku oraz Rada Nadzorcza umożliwiając dostęp do nowoczesnych technologii powinny analizować przede wszystkim ich zasadność w kontekście ryzyka i złożoności systemu teleinfor- 
matycznego oraz, powołując komitet do spraw bezpieczeństwa środowiska teleinformatycznego, wyznaczyć osobę, która posiada odpowiednie kompetencje w obszarze bezpieczeństwa tego środowiska (w sytuacji, gdy żaden z członków Zarządu nie posiada takich kwalifikacji, powoływany jest pełnomocnik) [KNF, 2013, s. 8]. Niniejsza Rekomendacja D stanowi niejako uzupełnienie Rekomendacji M dotyczącej zarządzania ryzykiem operacyjnym w bankach [KNF, 2013], gdyż bezpieczeństwo teleinformatyczne obarczone jest przede wszystkim ryzykiem operacyjnym. Tu również kluczowa okazuje się rola Spółdzielczej Grupy Bankowej, która, jako Bank Zrzeszający, odpowiedzialna jest za implementację wytycznych Komisji Nadzoru Finansowego. Stworzyła ona wspólną standardowa procedurę postępowania, uwzględniająca jednak zasadę proporcjonalności [Dokument elektroniczny, tryb dostępu: http://prnews.pl/wiadomosci/rekomendacja-d-jako-instrukcja-dlabankow-w-swiecie-norm-i-standardow-3183727.html, data wejścia: 16.01.2017], przy dokonywaniu audytu bezpieczeństwa informatyzacji dla wszystkich banków z grupy wykorzystując i realizując m.in. ankietę, szkolenia, konsultacje, poradnik wdrożeniowy. Było to dla SGB wyzwaniem, gdyż projekt o znaczacych rozmiarach musiał być zrealizowany przy ograniczonych kosztach oraz ograniczonych zasobach ludzkich [Dokument elektroniczny, tryb dostępu: http://bs.net.pl/aktualnosci-zrzeszen/rola-banku-zrzeszajacego-we-wspieraniu-bs-ow-wdrazajacych-rekomendacje-d, data wejścia: 16.01.2017].

\section{Wykorzystanie nowoczesnych rozwiązań technologicznych i produktowych na przykładzie Gospodarczego Banku Spółdzielczego Międzyrzecz na podstawie badań własnych}

Polem badawczym niniejszego opracowania jest wykorzystanie nowoczesnych technologii w bankowości spółdzielczej jako czynnik konkurencji na lokalnych rynkach usług bankowych. Sektor bankowości spółdzielczej kojarzony z tradycyjną obsługą klienta w placówce banku, rozwija się dynamicznie, co wpływa na konieczność wdrażania bezpiecznych i nowoczesnych technologii. Banki spółdzielcze podejmują próbę dorównania konkurencji inwestując w nowoczesne technologie, co zaskakuje, gdyż dotychczas to sektor banków komercyjnych wyznaczał trendy w bankowości. Implementacja biometrii w bankomatach przez banki spółdzielcze pozwala konkurować na lokalnych rynkach. W badaniu dąży się do analizy postaw klientów Gospodarczego Banku Spółdzielczego w Międzyrzeczu wobec wykorzystania nowoczesnych technologii.

Badanie jakościowe zostało przeprowadzone w okresie grudzień 2016 - luty 2017 wśród klientów GSB Międzyrzecz powyżej 18 roku życia. Wykorzystano metodę doboru losowego tak, aby każda jednostka populacji miała jednakową szansę dostania się do próby. Jako narzędzie badawcze przyjęto kwestionariusz autorskiej ankiety, z zachowaniem anonimowości udzielanych odpowiedzi. Kwestionariusz zawierał 13 pytań w temacie podjętej problematyki oraz 6 pytań o charakterze społeczno-demograficznym. Realizacja badania nastapiła dwutorowo: osobiście w obec- 
ności ankietera (128) oraz przez wypełnienie ankiety drogą elektroniczną (52). Procesowi ankietyzacji poddano łącznie 180 respondentów. Zebrany materiał badawczy został pogrupowany i poddany dalszej analizie metoda opisowa. Dla zdiagnozowania przyczyn wpływających na podejście do usługi biometrii, do oceny siły związku zmiennych, wpływających na nastawienie respondentów do usługi biometrycznej wykorzystano współczynnik kontyngencji C Pearsona oparty na teście niezależności chi-kwadrat $\chi 2$. Analiza statystyczna została wykonana $\mathrm{z}$ zastosowaniem programu StatSoft Statistica 10.

Na kanwie tradycyjnej działalności GBS Międzyrzecz podjęto próbę holistycznego rozpoznania, która $z$ usług bankowych jest istotna dla badanej grupy respondentów. Jak wynika $z$ badania, preferowanym kanałem kontaktu $z$ bankiem jest obsługa w oddziale i przywiązanie do płatności gotówką (42,8\%). Obserwuje się zależność, co do wieku respondentów. Im starsze pokolenie, tym bankowość tradycyjna ma większe znaczenie (patrz: tabela - aneks). Wykorzystanie tradycyjnych kanałów dostępu deklaruja przede wszystkim osoby z wykształceniem zawodowym, osiagające dochody od 1000-2000 zł, zamieszkujące miasta do 10 tys. mieszkańców i wsie. Na drugim miejscu znaleźli się respondenci, którzy cenią sobie dostęp do bankowości internetowej (38,3\%). Pod względem wieku granica się rozmywa, gdyż z bankowości internetowej korzystaja zarówno osoby do 25 roku życia oraz osoby w wieku 55 lat. W większości są to osoby $z$ wykształceniem średnim i wyższym, osiagające dochody od 1000-2000 zł, zamieszkujące małe i średnie miasta do 50 tys. mieszkańców i wsie. Zdecydowanie rzadziej wykorzystywane są płatności w terminalach POS i korzystanie z bankomatu (11,7\%). Warto podkreślić, że nie odnotowano istotnych różnic pod względem wieku i wykształcenia. Dochód ma wpływ na aktywność w obszarze płatności POS i korzystania z bankomatu wśród respondentów, których wartość ta kształtowała się na poziomie od 1000-2000 zł. Najczęściej są to osoby z miejscowości do 10 tys. mieszkańców. W mniejszości, klienci GBS Międzyrzecz uważaja, że bankowość mobilna $(6,7 \%)$ i home banking $(0,5 \%)$ to ważne dla nich kanały kontaktu z bankiem (wykres 2). Nie poddano analizie preferencji kanałów kontaktu z bankiem pod względem płci ze względu na brak znaczących różnic w deklaracjach respondentów oraz liczebności uczestniczących w badaniu.

Skupiono uwagę na postawach respondentów wobec bankowości mobilnej, analizując wykorzystanie aplikacji na smartfonie. Ponadto zbadano, co wpływa na korzystanie z usługi cash back oraz bankowości internetowej. W wyniku analizy danych stwierdza się, iż bankowość mobilna nie jest popularną formą realizacji usług $(27,8 \%)$. Wśród respondentów $(71,7 \%)$, którzy nie korzystają z bankowości mobilnej znaleźli się również klienci, którzy nie wiedzą o takiej usłudze bądź zadeklarowali, że ich bank takiej usługi nie oferuje $(0,5 \%)$. Fakt stosunkowo niewielkiej powszechności korzystania i niskiej aktywności w tym obszarze może być skutkiem niedostateccznej wiedzy w zakresie nowych narzędzi (smarfony) oraz ograniczonego kapitału. Analizując popularność bankowości terminalowej pominięto standardowe transakcje wykonywane $\mathrm{w}$ bankomacie, skupiono uwage na usłudze cash back. 
Ponownie zaobserwowano niski odsetek osób korzystających $(33,3 \%)$ z usługi wypłaty gotówki w terminalu POS.

WYKRES 2.

Preferowane kanały kontaktu z bankiem GSB Międzyrzecz, N=180

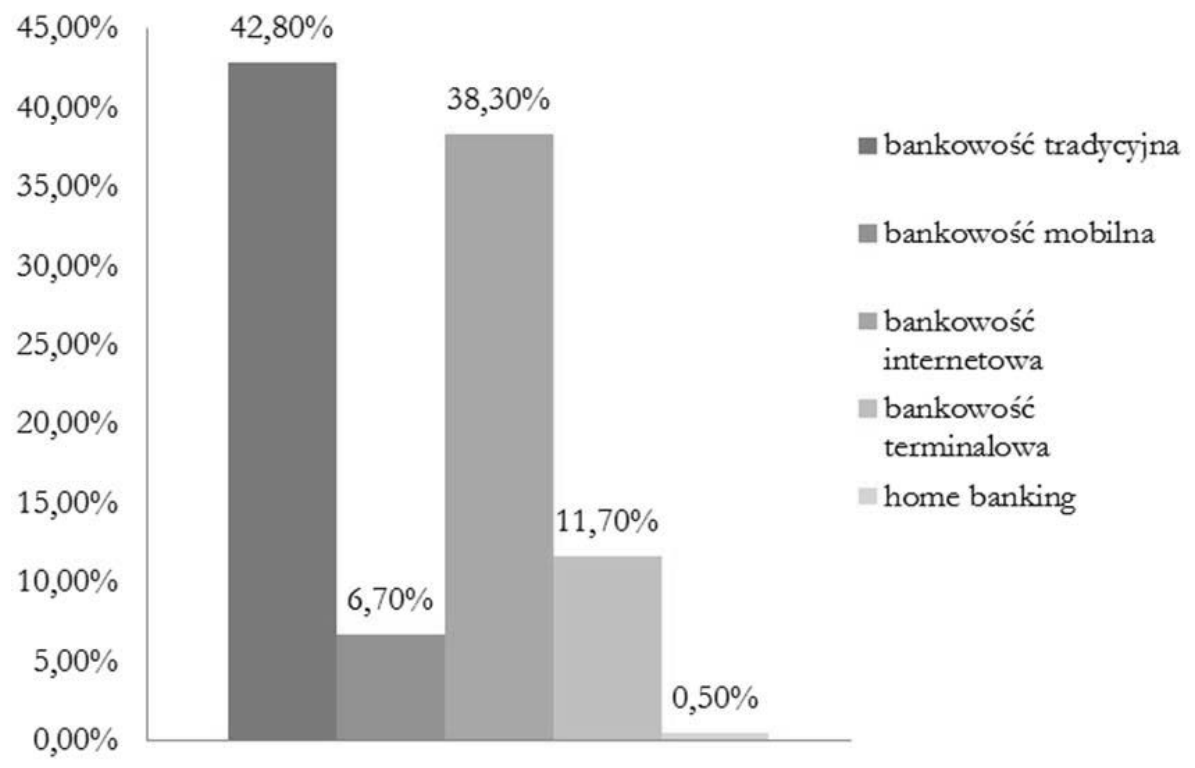

Źródło: opracowanie własne.

Ponad połowa respondentów $(58,4 \%)$ zadeklarowała, że nie korzysta z tej usługi. Niewielki odsetek $(3,9 \%)$ respondentów nie miał wiedzy o takiej usłudze. Wśród ankietowanych znaleźli się respondenci (4,4\%), którzy nie zdecydowali się udzielić informacji $\mathrm{w}$ analizowanym obszarze. Zaobserwowano, że najczęstszym powodem korzystania z usługi cash back jest wygoda oraz oszczędność czasu (wykres 3). Następnie, wskazywane są powody związane z brakiem bankomatów w najbliższym otoczeniu. Niewielkie koszty związane z wypłata gotówki przez usługę cash back również nie stanowią głównej przesłanki aktywności klientów.

W przypadku bankowości internetowej klientów GBS Międzyrzecz analiza obejmuje częstotliwość korzystania, przesłanki i najczęściej wykonywane operacje bankowe. Wyniki badania przedstawiają brak aktywności (36,9\%) respondentów w logowaniu się do systemu bankowości przez Internet. Wśród deklarujących taką aktywność, rzadziej niż raz w miesiącu loguje się $(1,1 \%)$, raz w miesiącu $(10,8 \%)$, kilka razy w miesiącu $(25,6 \%)$ było najczęstszą udzielaną odpowiedzią. W grupie respondentów korzystających $z$ większą częstotliwością znalazły się osoby logujące się raz w tygodniu $(5,6 \%)$, kilka razy w tygodniu $(16 \%)$ i codziennie $(4 \%)$. 
WYKRES 3.

\section{Przesłanki korzystania z usługi cash back w banku GBS Międzyrzecz (pytanie wielkokrotnego wyboru), $\mathrm{N}=60$}

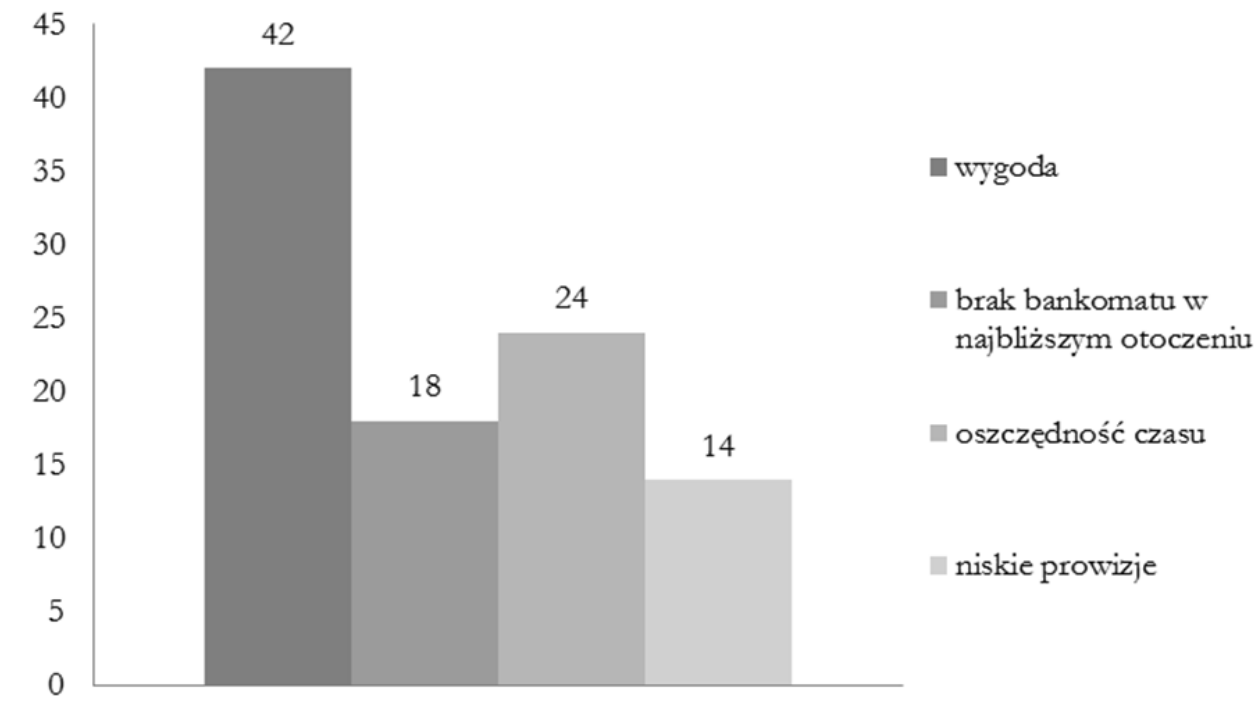

Źródło: opracowanie własne.

Analiza wykonywanych operacji bankowych za pośrednictwem bankowości internetowej (wykres 4) przedstawia tradycyjność wykorzystania tego kanału dostępu. Najczęściej wykonywane sa płatności stałe, tj. przelewy $(41,1 \%)$ i sprawdzenia historii i stanu konta (15\%). Może to nasuwać wniosek, że klienci banku posiadają narzędzia do korzystania z bankowości internetowej, lecz ich nie stosuja, wykorzystując inne rodzaje bankowości elektronicznej lub preferuja korzystanie z tradycyjnych kanałów dostępu.

Bezpieczeństwo realizowanych transakcji ma istotne znaczenie dla badanej grupy, co przedstawiają deklaracje „raczej tak” (na zadane pytanie o poczucie bezpieczeństwa) tak dla bankowości terminalowej (50,5\%) jak i mobilnej (45,6\%). Druga grupę stanowią respondenci, którzy nie zdecydowali się udzielić odpowiedzi, dla bankowości terminalowej $(28,9 \%)$ i mobilnej (30,6\%). Trzecia grupa to klienci banku, którzy nie czują się bezpieczni, deklarując „raczej nie” dla bankowości terminalowej $(12,8 \%)$, mobilnej $(14,4 \%)$. Wskazania „zdecydowanie nie”, „zdecydowanie tak” stanowily skrajne odpowiedzi. 


\section{Wykorzystanie bankowości internetowej przez klientów GBS Międzyrzecz, $\mathbf{N}=118$}

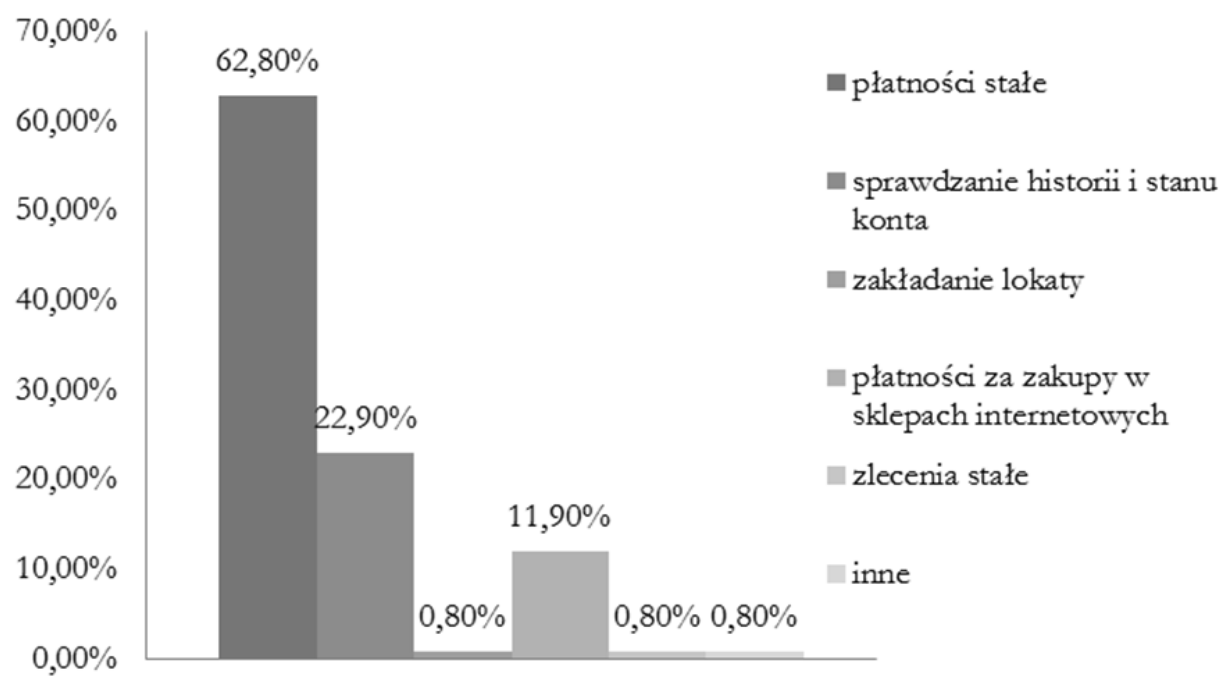

Źródło: opracowanie własne.

Ponadto w badaniu przeanalizowano postrzeganie bankowości elektronicznej przez klientów GBS Międzyrzecz. Mając na uwadze subiektywizm wypowiedzi respondentów, odnotowano, że klienci zgadzają się ze stwierdzeniem, iż „bankowość elektroniczna jest ważna i wyróżnia bank, w którym posiadają rachunek bankowy" $(58,3 \%)$. Tylko niewielki odsetek respondentów $(7,2 \%)$ uważa przeciwnie. Pozostali respondenci $(34,5 \%)$ nie mieli zdania na ten temat. Świadczy to o (tylko) zadowalającym poziomie świadomości ekonomicznej badanej grupy, co potwierdza wnikliwa analiza deklaracji respondentów w obszarze usługi biometrycznej.

W nawiązaniu do pionierskiej usługi uwierzytelniania biometrycznego na polskim rynku, dokonano analizy (wykres 5), czy klienci GBS Międzyrzecz wyrażają skłonność korzystania z takiej usługi, czy nie odczuwają takiej potrzeby. Portfel badanego podmiotu nie obejmuje jeszcze tej nowoczesnej usługi, zatem otrzymane wyniki badań mogą stać się przyczynkiem do ich kontynuacji w celu zniwelowania potencjalnych barier i obaw w przyszłości. Wskazać należy wciąż duże obawy przed tym nowatorskim rozwiązaniem, gdyż ponad połowa (61\%) respondentów nie skorzystałaby z usługi biometrycznej, gdyby była dostępna. Z drugiej strony znaleźli się klienci pozytywnie nastawieni do biometrii (39\%).

Dążąc do zdiagnozowania potencjalnych przyczyn wpływających na nastawienie klientów do usługi biometrycznej, przeanalizowano wpływ wieku, wykształcenia, miesięcznego dochodu i miejsca zamieszkania na podjęcie decyzji o skorzystaniu z usługi biometrycznej (tabela 2). W tym celu, w drodze ankietyzacji, zadano pytanie 
„Czy skorzystałbyś/-abyś z usługi biometrycznej, gdyby była dostępna w Twoim banku?".

WYKRES 5.

\section{Postawy klientów GBS Międzyrzecz wobec usługi biometrycznej} $\mathbf{N}=180$

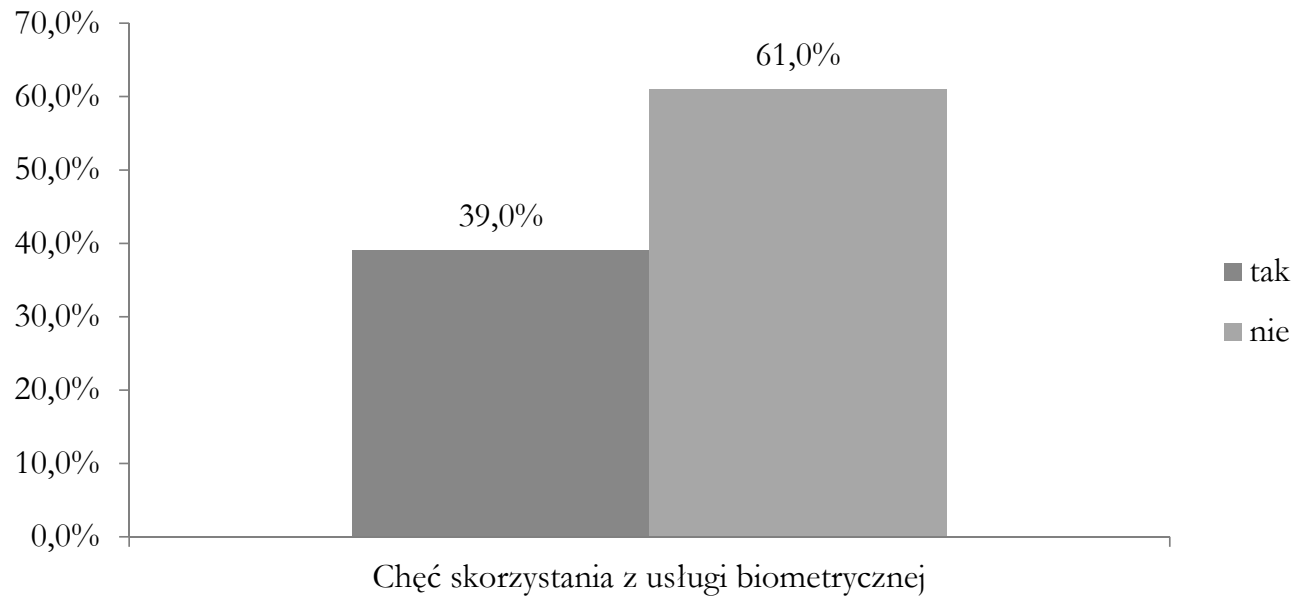

Źródło: opracowanie własne.

Analiza deklaracji respondentów w stosunku do usługi biometrycznej została podjęta przez weryfikację sił związku między zmiennymi jakościowymi, nominalnymi i niemierzalnymi. Do oceny zależności między zmiennymi wykorzystano współczynnik kontyngencji C Pearsona, który przyjmuje wartości od 0 do 1 [Chromińska, Roeske-Słomka i Szuman 2008, s. 109], gdzie:

gdzie:

0 - oznacza niezależność dwóch zmiennych,

1 - oznacza bardzo silną zależność pomiędzy zmiennymi

Do opisu siły związków zastosowano przyjętą przez autorki skalę:

$0,0<\mathrm{C}_{\mathrm{KOR}}<0,1 \quad$ bardzo słaba,

$0,1<\mathrm{C}_{\mathrm{KOR}}<0,3 \quad$ słaba,

$0,3<\mathrm{C}_{\mathrm{KOR}}<0,5 \quad$ średnia/przeciętna,

$0,5<\mathrm{C}_{\mathrm{KOR}} \leq 0,7 \quad$ silna,

$0,7<\mathrm{C}_{\mathrm{KOR}} \leq 0,9 \quad$ bardzo silna,

$0,9<\mathrm{C}_{\mathrm{KOR}} \leq 1,0 \quad$ doskonała.

Dążąc do wyznaczenia wartości współczynników kontyngencji C Pearsona (tabela 3) wykorzystano tabele krzyżowe i przyjęto poziom istotności $\alpha=0,05$. Wyniki badania przedstawiają zależność płci, wieku, wykształcenia, dochodów i miejsca zamieszkania respondentów do preferencji skorzystania z usługi biomet- 
rycznej. Weryfikacja wpływu płci na podjęcie decyzji o skorzystaniu z usługi biometrycznej wskazuje, że zachodzi słaba zależność. Obliczona wartość statystyki chi-kwadrat $=1,62$ była mniejsza od wartości krytycznej chi-kwadrat $=3,8415$ odczytanej z tablic dla poziomu istotności $\alpha=0,05$ i 1 stopnia swobody. Słaba siła związku między zmiennymi $\mathrm{C}_{\mathrm{KOR}}=0,13$ wskazuje na znikome znaczenie płci na decyzje o skorzystaniu z usług biometrii w przyszłości. Ponadto, przeanalizowano wpływ wieku na decyzje o skorzystaniu z biometrii. Wskazuje się słabą zależność między wiekiem a deklaracjami respondentów. Najliczniejszą grupę pozytywnie nastawionych klientów stanowiły osoby w przedziale wiekowym 46-55 lat (26). $\mathrm{Z}$ drugiej strony, brak skłonności najbardziej przejawiali respondenci z tej samej grupy wiekowej (30) oraz młodzi do 25 lat (21). Obliczona wartość statystyki chikwadrat $=4,21$ była mniejsza od wartości krytycznej chi-kwadrat $=11,0705$ odczytanej z tablic dla poziomu istotności $\alpha=0,05$ i 5 stopni swobody. Występuje słaba siła związku między zmiennymi $\mathrm{C}_{\mathrm{KOR}}=0,19$.

TABELA 3.

Chi-kwadrat i współczynnik kontyngencji C Pearsona między płcią, wiekiem, wykształceniem, dochodami, miejscem zamieszkania a skłonnością do skorzystania z usługi biometrycznej klientów GBS Międzyrzecz

\begin{tabular}{|l|c|c|c|c|c|c|c|}
\hline \multicolumn{1}{|c|}{ Zmienna } & $\begin{array}{c}\text { Chi- } \\
\text { kwadrat }\end{array}$ & $\boldsymbol{\chi}_{\boldsymbol{\alpha , \boldsymbol { d }} \mathbf{f}}^{\mathbf{2}}$ & $\mathbf{D f}$ & $\mathbf{P}$ (value) & $\begin{array}{c}\mathbf{C} \\
\text { Pearsona }\end{array}$ & $\mathbf{C}_{\text {MAx }}$ & $\mathbf{C}_{\text {KOR }}$ \\
\hline Płeć & 1,62 & 3,8415 & 1 & 0,203 & 0,09 & 0,71 & 0,13 \\
\hline Wiek & 4,21 & 11,0705 & 5 & 0,520 & 0,15 & 0,81 & 0,19 \\
\hline Wykształcenie & 7,30 & 7,8147 & 3 & 0,063 & 0,2 & 0,79 & 0,25 \\
\hline $\begin{array}{l}\text { Miesięczny dochód } \\
\text { (netto) }\end{array}$ & 8,62 & 11,0705 & 5 & 0,125 & 0,21 & 0,81 & 0,26 \\
\hline Miejsce zamieszkania & 9,05 & 9,4877 & 4 & 0,060 & 0,22 & 0,8 & 0,27 \\
\hline
\end{tabular}

Źródło: opracowanie własne, $\mathrm{N}=180, \alpha=0,05$.

Poddając analizie wykształcenie jako czynnik warunkujący decyzję o skorzystaniu $z$ usługi biometrycznej warto nadmienić, iż osoby z wykształceniem zawodowym (23), średnim (22) i wyższym (24) wykazują większą skłonność do jej wykorzystania, gdyby mieli taką możliwość. Najliczniejsza grupa ,niechętnych” były osoby z wykształceniem zawodowym (49). Obliczona wartość statystyki chi-kwadrat $=7,30$ była mniejsza od wartości krytycznej chi-kwadrat $=7,8147$ odczytanej $\mathrm{z}$ tablic dla poziomu istotności $\alpha=0,05$ i 3 stopni swobody. Występuje słaba siła związku między zmiennymi $\mathrm{C}_{\mathrm{KOR}}=0,25$. Istotny dla wnioskowania na temat uwierzytelniania biometrycznego jest poziom osiaganych dochodów. Na dwóch biegunach odnotowano najliczniejsza grupę respondentów, których dochód znajdował się między 1001-2000 zl netto. Nastawieni pozytywnie (38) i negatywnie (62). Obliczona wartość statystyki chi-kwadrat $=8,62$ była mniejsza od wartości krytycznej chi-kwadrat $=11,0705$ odczytanej z tablic dla poziomu istotności $\alpha=0,05$ i 5 stopni swobody. 
Występuje słaba siła związku między zmiennymi $\mathrm{C}_{\mathrm{KOR}}=0,26$. Weryfikacja miejsca zamieszkania daje powody wnioskować, iż wpływa ono najmocniej na podjęcie decyzji o skorzystaniu z biometrii. Głosy osób zamieszkujących miasta do 10 tys. mieszkańców rozłożyły się najliczniej w pozytywnym nastawieniu (36) i awersji do biometrii (61). Ponadto, drugą najliczniejsza grupa z awersją do biometrii były osoby zamieszkujące wieś (29). Obliczona wartość statystyki chi-kwadrat $=9,05$ była mniejsza od wartości krytycznej chi-kwadrat $=9,4877$ odczytanej z tablic dla poziomu istotności $\alpha=0,05$ i 4 stopni swobody. Występuje słaba siła związku między zmiennymi $\mathrm{C}_{\mathrm{KOR}}=0,27$.

Poczynione rozważania stanowia potwierdzenie słuszności założeń H0, iż klienci SGB Międzyrzecz dostrzegają rosnącą rolę nowoczesnych technologii. W wyniku przeprowadzonego postępowania, pomimo słabych zależności warunkujących wykorzystanie biometrii w przyszłości, wnioskuje się, że z prawdopodobieństwem $95 \%$ nie ma podstaw do odrzucenia H0. Zdaniem autorek, postrzeganie bankowości elektronicznej przez klientów GBS Międzyrzecz jako „ważnej i wyróżniającej bank, w którym posiadają rachunek bankowy" (58,3\%) stanowi dobrą podstawę do wzbudzenia procesów poznawczych i zdobywania wiedzy o nowoczesnych usługach. Wydaje się również, że deklaracje respondentów świadczyć mogą o konkurencyjności sektora bankowego względem banków komercyjnych. Satysfakcja klientów $z$ dotychczasowej obsługi, uniwersalizm usług oraz brak potrzeby zmian oferenta usług, to elementy bardzo istotne w walce $\mathrm{z}$ konkurencja.

\section{Podsumowanie}

Zagadnieniem badawczym w niniejszym opracowaniu była analiza nowoczesnych rozwiązań technologicznych w GBS Międzyrzecz. Dążono również do rozstrzygnięcia, czy wdrożenie nowych technologii w sektorze BS przyczynia się do wzrostu ich konkurencyjności. W celu szczegółowej weryfikacji podjętej problematyki, na kanwie działalności Gospodarczego Banku Spółdzielczego Międzyrzecz, dokonano analizy w obszarze wdrażania nowoczesnych technologii na rynku lokalnym. Realizacja celu głównego służyła bezpośredniej weryfikacji hipotezy badawczej, którą jest stwierdzenie, że klienci GBS Międzyrzecz dostrzegają rosnącą rolę nowoczesnych technologii.

Banki spółdzielcze prowadzą intensywne działania przyczyniające się do wprowadzania nowoczesnych rozwiązań technologicznych, co stawia je na konkurencyjnej pozycji w stosunku do banków komercyjnych, pomimo mniejszego zaangażowania kapitałowego. Daje to podstawy do pozytywnego postrzegania banków spółdzielczych jako nowoczesne instytucje świadczące kompleksowo usługi finansowe. Bank poddany analizie w opracowaniu wpisuje się w tendencję zmian strategicznych sektora spółdzielczego, dążąc do wykorzystania potencjału technologicznego i zasobów, które posiada, oferując różne kanały dostępu. Zebrany materiał badawczy, niestety, nie pozwala na huraoptymizm w przypadku postrzegania usługi biometrycznej przez klientów GBS Międzyrzecz. 
Zdiagnozowano, iż klienci GBS Międzyrzecz pomimo dostępu do narzędzi do wykorzystania bankowości elektronicznej nie przejawiają skłonności do nowoczesnych technologii, nie posiadaja dostatecznej wiedzy w tym obszarze oraz nie maja poczucia bezpieczeństwa wykonywanych transakcji, co nie pozwala na zmianę postawy. Wskazuje się niedostateczne wykorzystanie zdalnych kanałów dostępu, podczas gdy, świadomość klientów GBS Międzyrzecz, o istotnej roli tej usługi, jest na wysokim poziomie. Uzyskane wyniki nie świadczą jednakże o jednoznacznym przywiązaniu do tradycyjnej obsługi w oddziale. Wybór tradycyjnego modelu bankowości ,goni” bankowość internetowa, co przedstawiają wyniki badań.

Podjęta problematyka nieustanie wymaga poznawczego zgłębienia, a kolejne opracowania teoretyczne i empiryczne pozwola na diagnozę potrzeb i oczekiwań klientów. Należy podkreślić, że potrzeba edukacji finansowej i zwiększania świadomości klientów na temat nowoczesnej obsługi produktów jest ogromna. Wyzwaniem dla banków spółdzielczych staje się konkurowanie na rynkach lokalnych przez wdrażanie nowoczesnych rozwiazzań technologicznych i produktowych, bez utraty klientów przywiązanych do tradycyjnego kontaktu.

TABELA - ANEKS

Preferowane kanały kontaktu $\mathrm{z}$ bankiem a zmienne objaśniające

\begin{tabular}{|c|c|c|c|c|c|c|c|c|c|c|c|c|c|c|c|c|c|c|c|c|c|c|c|}
\hline \multirow[b]{2}{*}{ Zmienna } & \multicolumn{2}{|c|}{ Płeć } & \multicolumn{6}{|c|}{ Wiek } & \multicolumn{4}{|c|}{ Wykształcenie } & \multicolumn{6}{|c|}{ Dochód } & \multicolumn{5}{|c|}{$\begin{array}{c}\text { Miejsce } \\
\text { zamieszkania }\end{array}$} \\
\hline & $\mathbf{K}$ & $\mathbf{M}$ & กิ & 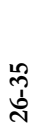 & 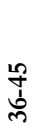 & $\begin{array}{l}10 \\
1 \\
1 \\
+\end{array}$ & 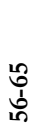 & $\stackrel{20}{\wedge}$ & a & $\mathbf{N}$ & $\infty$ & $\geqslant$ & 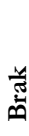 & $\frac{8}{\mathrm{~g}}$ & 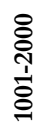 & 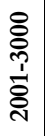 & 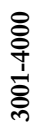 & ஓ̊̊̆ & $\stackrel{\mathscr{Q}}{\pi}$ & $\begin{array}{l}\dot{\infty} \\
\stackrel{2}{2} \\
\stackrel{1}{\Lambda}\end{array}$ & $\frac{8}{1}$ & 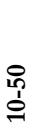 & $\stackrel{ }{\mathrm{V}}$ \\
\hline $\begin{array}{l}\text { Bankowość } \\
\text { tradycyjna }\end{array}$ & 55 & 22 & 0 & 2 & 11 & 32 & 16 & 16 & 6 & 47 & 16 & 8 & 1 & 4 & 54 & 16 & 2 & 0 & 16 & 5 & 2 & 9 & 45 \\
\hline $\begin{array}{l}\text { Bankowość } \\
\text { mobilna }\end{array}$ & 5 & 7 & 5 & 4 & 1 & 2 & 0 & 0 & 0 & 2 & 5 & 5 & 2 & 4 & 3 & 2 & 1 & 0 & 3 & 2 & 1 & 2 & 4 \\
\hline $\begin{array}{l}\text { Bankowość } \\
\text { internetowa }\end{array}$ & 46 & 23 & 20 & 16 & 10 & 18 & 5 & 0 & 1 & 16 & 25 & 27 & 3 & 5 & 30 & 17 & 10 & 4 & 16 & 2 & 0 & 16 & 35 \\
\hline $\begin{array}{l}\text { Bankowość } \\
\text { termina- } \\
\text { lowa }\end{array}$ & 17 & 4 & 6 & 4 & 4 & 4 & 2 & 1 & 1 & 7 & 7 & 6 & 1 & 2 & 13 & 2 & 3 & 0 & 5 & 3 & 0 & 1 & 12 \\
\hline $\begin{array}{l}\text { Home } \\
\text { banking }\end{array}$ & 0 & 1 & 1 & 0 & 0 & 0 & 0 & 0 & 0 & 0 & 1 & 0 & 0 & 0 & 0 & 1 & 0 & 0 & 0 & 0 & 0 & 0 & 1 \\
\hline Suma & 123 & 57 & 32 & 26 & 26 & 56 & 23 & 17 & 8 & 72 & 54 & 46 & 7 & 15 & 100 & 38 & 16 & 4 & 40 & 12 & 3 & 28 & 97 \\
\hline
\end{tabular}

Źródło: opracowanie własne. 


\section{Literatura}

Chromińska M., Roeske-Słomka I., Szuman A., 2008, Wnioskowanie statystyczne, Akademia Ekonomiczna w Poznaniu, „Zeszyty Studium Doktoranckiego”, z. 2, Poznań.

Czechowska I., 2013, Ograniczenia w dostepie do ustug bankonych klientón 60+ w perspektywie zrónnoważonych finansów, [w:] Rola instytugi i iynku finansowego w swietle celów oraz. zasad zrómnoważonego rozwoju, G. Borys, A. Janusz (red.), Wrocław.

Dokumen.t elektroniczny, tryb dostępu: http://bs.net.pl/prawo/wplyw-nowoczesnych-technologii-bankowych-w-zwiekszaniu-pozycji-rynkowej [data wejścia: 14.01.2017].

Dokument elektroniczny, tryb dostępu: http://bs.net.pl/aktualnosci-zrzeszen/rolabanku-zrzeszajacego-we-wspieraniu-bs-ow-wdrazajacych-rekomendacje-d [data wejścia: 16.01.2017].

Dokument elektroniczny, tryb dostępu: http://prnews.pl/raporty/raport-prnewsplrynek-bankowosci-mobilnej-iii-kw-2016-6553439.html [data wejścia 05.01.2017].

Dokument elektroniczny, tryb dostępu: http://prnews.pl/wiadomosci/rekomendacja-d-jako-instrukcja-dla-bankow-w-swiecie-norm-i-standardow-3183727.html [data wejścia: 16.01.2017].

Dokument elektroniczny, tryb dostępu: http://serwisy.gazetaprawna.pl/finanseosobiste/artykuly/970019,platnosci-hce-w-bankach-spoldzielczej-grupybankowej.html [data wejścia: 12.01.2017].

Dokument elektroniczny, tryb dostępu: http://www.automatykabankowa.pl/bankomat-bezgotowkowy-ciekawostka-czy-rewolucja-w-wyplatach-samoobslugowychw-firmach-retail [data wejścia: 04.01.2017].

Dokument elektroniczny, tryb dostępu: http://www.bain.com/Images/ WEF_2009 _Mobile_internet.pdf [data wejścia 11.01.2017].

Dokument elektroniczny, tryb dostępu: http://www.bankier.pl/wiadomosc/Za-cochwalimy-banki-spoldzielcze-2555338.html [data wejścia: 14.01.2017].

Dokument elektroniczny, tryb dostępu: http://www.forbes.pl/historia-bankomatu, artykuly, 195302,1,1.html [data wejścia: 02.01.2017].

Dokument elektroniczny, tryb dostępu: http://www.gbsmiedzyrzecz.pl/o-nas/bankomaty.html [data wejścia: 13.01.2017].

Dokument elektroniczny, tryb dostępu: http://www.gbsmiedzyrzecz.pl/o-nas/ placowki.html [data wejścia: 12.01.2017].

Dokument elektroniczny, tryb dostępu: http://www.ioz.pwr.wroc.pl/Pracownicy/ mercik/zbiory/ Prezentacje\%202007/grupa4-\%20Bankowo.pdf [data wejścia: 11.01.2017].

Dokument elektroniczny, tryb dostępu: http://www.krs-online.com.pl/gospodarczy-bank-spoldzielczy-miedzyrzecz-archiwum-6837636-80090.html [data wejścia: 12.01.2017].

Dokument elektroniczny, tryb dostępu: http://www.pkobp.pl/grupa-pko-bankupolskiego/pko-bank-polski/historia/rys-historyczny [data wejścia: 15.01.2017]. 
Dokument elektroniczny, tryb dostępu: http://www.spidersweb.pl/2015/02/blikstart-platnosci.html [data wejścia: 14.01.2017].

Dokument elektroniczny, tryb dostępu: https://bodie.pl/blog/masz-bank-pod-reka, 22? $\mathrm{p}=8$ [data wejścia: 04.02.2018].

Dokument elektroniczny, tryb dostępu: https://www.novum.pl/index.php/biometria-w-bankach-spoldzielczych [data wejścia: 07.02.2017].

Dokument elektroniczny, tryb dostępu: https://www.visa.pl/o-nas/aktualnosci/ mobilne-platnosci-zblizeniowe-visa-oparte-o-chmure-w-spoldzielczej-grupie-bankowej-1666262? returnUrl=/o-nas/aktualnosci/index [data wejścia: 12.01.2017].

Dokument elektroniczny, tryb dostępu: www.ptzp.org.pl [data wejścia: 11.01.2017].

Dz.U. 1997 nr 140 poz. 939, Ustawa Prawo Bankowe z dnia 29 sierpnia 1997 r.

Dz.U. 2000 nr 911 poz. 1252, Ustawa o funkcjonowaniu banków spółdzielczych, ich zrzeszaniu się i bankach zrzeszających z dnia 7 grudnia $2000 \mathrm{r}$.

Dz.U. 2000 nr 94 poz. 1037, Ustawa Kodeks spółek handlowych z dnia 15 września $2000 \mathrm{r}$.

Dz.U. 2011 nr 199 poz. 1175, Ustawa o usługach płatniczych z dnia 19 sierpnia $2011 \mathrm{r}$.

Gasparski W., 2012, Biænnes, etyka, odpowiedzৃialność, PWN, Warszawa.

Gawrychowski M., 2016, Banki w sieci, [w:] Pewne jak w banku, Narodowy Bank Polski, Warszawa.

Główny Urząd Statystyczny, Ludność. Stan i struktura w przęeroju terytorialnym, stan w dniu 30 czerwca 2016.

Gorynia M., Jankowska B., 2008, Klastry a międzynarodowa konkurencyjność i internacjonalizacja przedsiebiorstwa, Difin, Warszawa.

Gorzeń-Mitka I., 2016, Determinanty konkurencyjności przeedsiębiorstw, [w:] Prz̨edsiębiorstwo i państwo - wybrane problemy konkurencyjności, T. Bernata (red.), PrintGroup, Szczecin.

Gospodarczy Bank Spółdzielczy Międzyrzecz, Materiały wewnętrzne Gospodarczego Banku Spółdzielczego, Międzyrzecz 2017.

Gospodarczy Bank Spółdzielczy Międzyrzecz, Præeewodnik po Bankowości Mobilnej Mobile Banking, Międzyrzecz, czerwiec 2014.

Górka J. H., 2006, Specyfikacja rysyyka bankowości elektronicznej, „Materiały i Studia”, z. 205, Narodowy Bank Polski, Warszawa.

Janc A., 2004, Wspótczesny bank $i$ jego otoczenie $w$ dobie rewolucji informatycznej, red. A. Janc, G. Kotliński (red.), Wydawnictwo Akademii Ekonomicznej w Poznaniu.

Klimczuk A., 2012, Supporting the Development of Gerontechnology as Part of Silver Economy Building, AD ALTA: "Journal of Interdisciplinary Research", Hradec Králové.

KNF, 2010, Ustugi bankowości elektronicznej dla klientón detalicznych: charakterystyka i zagro:̇enia, Warszawa.

KNF, 2013, Rekomendacja D dotyczaca zarzadzania obszarami technologii informacyjnej i bezpieczeństwa środowiska teleinformatycznego w bankach, Warszawa.

KNF, 2016, Informacja o sytuacji bankón spótdzielcsych i zrzeszajacych w I kw. 2016 r., Warszawa.

Kotliński G., 2012, Problemy informatyzacïi dzৃiałalności banków spótdzielcsych, [w:] Wspótczesna bankowość spótdrielcza, A. Szelagowska (red.), CeDeWu, Warszawa. 
Koźliński T., 2013, Zuyczaje platnicze Polaków, Narodowy Bank Polski, Warszawa.

Martyniuk Z., 2007, C\&ynniki i bariery rozwoju technologii informatycznej w bankach komercyjnych w Polsce, „Annales Universitatis Mariae Curie-Skłodowska. Sectio H, Oeconomia", t. 41 - Finanse i Rachunkowość, Lublin.

Mórawski K., J., 2016, Tyle technologii, ile potrzeba - tyle bankowości, ile jest możlinve, „Nowoczesny Bank Spółdzielczy”, 6.

Orłowski J., 2015, Jakich oddziałón bankonych potrzebuja dzisiaj kliencr? Czy zdalne kanały obsługi zastąpią oddziały bankowe?, „Bank Spółdzielczy”, nr 6/583.

Parys T., 2003, Bankowość internetowa jako nowa forma swiadczenia ustug bankonych, [w:] Systemy wspomagania organizacji SWO'2003, „Prace Naukowe Akademii Ekonomicznej w Katowicach", Katowice.

Pawęda D., 2016, Fintech - szansa çy zagrożenie dla wspótcžesnej bankowości?, „Nowoczesny Bank Spółdzielczy", nr 10.

Pawłowska M., 2014, Konkurencja w sektorze bankowym: teoria $i$ uyniki empiryczne, Wydawnictwo C.H. Beck, Warszawa.

Polasik M., 2005, Rozwój bankowości elektronicznej w Polsce - w świetle badań ankietowych, „Bank i kredyt”, Narodowy Bank Polski, Warszawa.

Polasik M., 2006, Bankowość elektronična, CeDeWu, Warszawa.

Rosa A., 2013, Konkurencyjnosí sektora banków spótdzielcaych w Polsce, „Zarządzanie i Finanse", t. 2, nr 1, Wydział Zarządzania - Uniwersytet Gdański.

Spółdzielcza Grupa Bankowa, 2016, Płatności z̧bliženiowe HCE, „Informator SGB” 3.

Szambelańczyk J., 2004, Perspektywy rozwoju banków spótdzielczych w Polsce w warunkach integracji i globalizacji rynków finansonych, „Ruch Prawniczy, Ekonomiczny i Socjologiczny", z. 3.

Ślązak E., Borowski K., 2007, Bankowość elektronicz̨na, [w:] Wspótczesna bankowość, M. Zaleska (red.), Difin, Warszawa.

Świecka B., 2008, Bankowośc elektronična, CeDeWu, Warszawa.

Uchwała nr 7/2013 Komisji Nadzoru Finansowego z dnia 8 stycznia 2013 r. w sprawie wydania Rekomendacji D dotyczącej zarządzania obszarami technologii informacyjnej i bezpieczeństwa środowiska teleinformatycznego w bankach.

Warchlewska A., 2012, Banki spótdžielcze w zapobieganiu uykluczeniu finansowemu (prayyczynek do badan), [w:] Wybrane historyczne i wspótczesne aspekty rozwoju banków spótdrielçych w Polsce, A. Stefański (red.), Wyższa Szkoła Humanistyczno-Ekonomiczna we Włocławku, Włocławek.

Zalewska-Bochenko A., 2013, Bankowośćc telefoniczna i jej wplyw na bankowość elektroniçৃna, „Innowacje w Bankowości i Finansach”, t. 1, nr 173. 